\title{
Standardization of process line for preparation of unripe banana shrikhand
}

\author{
D.R. BHOYAR, P.A. KAHATE, R.R. SHELKE AND H.V. WADATKAR
}

\begin{abstract}
The present investigation entitled "Standardization of process line for preparation of unripe banana shrikhand" was undertaken in the Department of Animal Husbandry and Dairy Science, Dr. Panjabrao Deshmukh Krishi Vidyapeeth, Akola, during the year 2013-2014. The efforts were made to incorporate the nutritional value of banana in shrikhand and prepared the value added fermented dairy product. The investigation was planned with main objectives to standardize the process line for preparation of shrikhand, to standardize the optimum level of unripe banana pulp in shrikhand, sensory evaluation and determination of cost of production of shrikhand. Before blending unripe banana was cooked at $90^{\circ} \mathrm{C}$ for $5 \mathrm{~min}$. and prepare paste which improves sensory quality of shrikhand. It was found that blending of 20 per cent unripe banana in shrikhand produce a good and more acceptable quality shrikhand. Cost of production was reduced due to increase in the level of unripe banana pulp in shrikhand.
\end{abstract}

KEY WORDS : Shrikhand, Unripe banana pulp, Sensory evaluation, Cost of production

How TO CITE THIS PAPER : Bhoyar, D.R., Kahate, P.A., Shelke, R.R. and Wadatkar, H.V. (2014). Standardization of process line for preparation of unripe banana shrikhand. Res. J. Animal Hus. \& Dairy Sci., 5(2) : 136-139. 